\title{
Seaweed-mediated indirect interaction between two species of meso-herbivores
}

\author{
Hee Young Yun ${ }^{1, *}$, Sven Rohde ${ }^{2}$, Kevin Linnane ${ }^{3}$, Martin Wahl ${ }^{4}$, Markus Molis ${ }^{1}$ \\ ${ }^{1}$ Section Seaweed Biology, Biologische Anstalt Helgoland, Alfred Wegener Institute for Polar and Marine Research, \\ Marine Station, Kurpromenade 201, 27498 Helgoland, Germany \\ ${ }^{2}$ University of Guam, Marine Lab, Mangilao 96923, Guam \\ ${ }^{3}$ RPS Planning and Development, Conrad House, Beaufort Square, Chepstow, Monmouthshire NP16 5EP, UK \\ ${ }^{4}$ IFM-GEOMAR, Leibniz Institute of Marine Sciences, Düsternbrooker Weg 20, 24105 Kiel, Germany
}

\begin{abstract}
Previous studies on trait-mediated trophic interactions in marine ecosystems were restricted to pair-wise interactions between one species of meso-herbivore and plant, though multigrazer interactions are more common in nature. We investigated whether the feeding of one consumer, either the periwinkle Littorina littorea or the isopod Idotea baltica, affected consumption by the other consumer via anti-herbivory defence induction in the brown seaweed Fucus vesiculosus. To test the generality of our findings, we ran similar experiments with seaweed/grazer populations in the North and Baltic Seas (NE Atlantic). Grazer-specificity in induction strength was assessed by using the same species of grazer for induction and consumption. 'Indirect' induction effects were assessed by using different species of grazers for induction and consumption. Palatability assays were run with live algae and with reconstituted food to distinguish between different mechanisms of resistance. Grazing by herbivores induced a chemical defence in F. vesiculosus. In the North Sea population, the induced defences were only effective against $I$. baltica, regardless of inducer identity. The sensitive responses of $I$. baltica to the induced defences were also detected in the reconstituted food assays using Baltic Sea organisms. Thus, marine meso-grazers may be affected by previous feeding through the same or a different species of consumer by modified prey traits, such as induced chemical defences. Furthermore, the magnitude of the effect in the induced defences can be determined by species-specific sensitivity.
\end{abstract}

KEY WORDS: Multi-species interactions · Trait-mediated indirect interaction · Fucus vesiculosus • Idotea baltica $\cdot$ Littorina littorea $\cdot$ Herbivore-seaweed interactions

\section{INTRODUCTION}

Herbivory can strongly alter the structure and diversity of terrestrial and marine communities (reviewed by Duffy \& Hay 2000, Van Zandt \& Agrawal 2004). Herbivory may be a driver for the evolution of phenotypic plastic responses in plants (Karban \& Baldwin 1997, Toth \& Pavia 2007). Inducible anti-herbivore responses in plants could represent a more favourable strategy than constitutive defences where the risks from consumers are relatively high, but variable in space and time (Karban \& Nagasaka 2004). Herbivore-induced responses at the same time reduce the vulnerability of plants to consumers (reviewed by Karban \& Baldwin 1997) and modify the feeding behaviour of herbivores (Borell et al. 2004). Typically, the induced defence persists for some time, then is reduced again, either after grazing pressure ceases (Rohde \& Wahl 2008) or even before (Wahl et al. unpubl. data). Induced chemical defences may contribute to intra-specific signalling in plants (reviewed by Baldwin et al. 2006) and seaweeds (Toth \& Pavia 2000) and affect inter-specific interactions with other community members (Ohgushi 2005, Coleman et al. 2007, Denno \& Kaplan 2007). 
Several herbivore species with diverse dietary guilds in marine systems may share a single seaweed host (e.g. Buschbaum et al. 2006), providing arenas for multiple grazer interactions. Despite this, previous studies on marine communities have mainly focused on the effects of single herbivore species on trait changes in their single host alga, because competition among herbivores is not usually considered due to the supposed ubiquity of food (Strong et al. 1984). However, besides this direct consumer-consumer interaction, a consumption-induced modification of food quality may constitute trait-mediated indirect interactions among consumers (TMIIs) (reviewed by Schmitz et al. 2004, Fordyce 2006, Long et al. 2007).

While TMIIs may be powerful, the mediating trait, inducible defence, within a prey species may vary regionally (i.e. Long \& Trussell 2007). For instance, previous research on a congeneric species to that used in the present study, Fucus radicans, has shown that it exhibits different adaptive traits regionally, due to restricted gene flow (Bergström et al. 2005). Indeed, induction of anti-herbivore resistance as a plant property to mediate herbivore interactions can be geographically variable within a specific population (Long \& Trussell 2007). Also, herbivores may adapt to the local particularities of their hosts (Sotka \& Hay 2002, Jormalainen et al. 2008). Grazer tolerance to the chemical defences of algae may be broad but differ phylogenetically (Poore et al. 2007). Therefore, herbivoreherbivore interactions mediated by algal hosts may not only vary regionally but also with regard to the consumer group considered.

TMIIs are potentially of high ecological relevance, due to their immediate effects on the entire prey population when consumers are present (Peacor \& Werner 2001). To better understand whether TMIIs are generally important drivers in species interactions, 2 aspects of TMIIs need to be experimentally considered. First, it should be clarified whether the very few examples of TMIIs in marine systems depict a bias in research effort or a real pattern (Schmitz et al. 2004). Second, to assess regional variability, TMIIs of identical interaction webs should be compared between locations with different environmental conditions. In a recent study from North America, Long et al. (2007) suggested that an asymmetry in the competition for food between the periwinkles Littorina obtusata and L. littorea and the isopod Idotea baltica was mediated by trait changes in their shared food, the brown seaweed Fucus vesiculosus. In the present study, since a similar food web also exists along NE Atlantic shores, we examined the role of TMIIs in the food web with seaweed F. vesiculosus and the mesograzers $I$. baltica and L. littorea, at 2 different locations in the brackish Baltic Sea and the fully marine North Sea, respectively. First, we hypothesised that grazing decreases the palatability in F. vesiculosus. Second, we tested whether the grazing-induced response may be derived from a chemical origin. Third, we investigated whether grazing by a given herbivore species decreased the palatability of seaweed pieces for naïve conspecific or heterospecific consumers. To generalize induced response patterns, experiments were conducted with 2 regionally distinct (North and Baltic Seas) food webs of $F$. vesiculosus and its grazers.

\section{MATERIALS AND METHODS}

Sampling sites and organisms. Laboratory experiments were conducted with the gastropod Littorina littorea, the isopod Idotea baltica, and the brown seaweed Fucus vesiculosus, which were collected at 2 NE Atlantic sites: (1) at Bülk (54 $26^{\prime} \mathrm{N}, 10^{\circ} 11^{\prime} \mathrm{E}$ ) in the Kiel Fjord (western Baltic Sea) and (2) at Bunker (54 $11^{\prime} \mathrm{N}$, $7^{\circ} 52^{\prime} \mathrm{E}$ ) in the Nordwatt of Helgoland (southern North Sea). These sites are ca. $900 \mathrm{~km}$ apart by seaways and differ with respect to their abiotic conditions. The Baltic Sea is an almost atidal (tidal range $<10 \mathrm{~cm}$ ), semi-enclosed, brackish sea (salinity of 15 at the collection site) of relatively young geological age. In contrast, the North Sea has a tidal range of $>2.35 \mathrm{~m}$ at the collection site, is fully marine (salinity of 33 at the collection site) and represents a geologically older marine environment than the Baltic Sea. The distribution of the fauna and flora in the Baltic Sea reflects a depleted sub-set of the North Sea biota, indicating similarity in biotic conditions at both sites to a certain extent.

Experimental set-up and design. Induction of antiherbivore defences: To test the causes and effects of herbivory-induced defence at the regional scale, identical 21 d laboratory experiments were conducted at the IFM-Geomar (Baltic Sea) and Biologische Anstalt Helgoland (North Sea).

Twenty individuals of Fucus vesiculosus without visible grazing marks were collected from the shore at each region and immediately transported to the laboratory. Ten apical pieces of similar length of each $F$. vesiculosus specimen were cut, and all visible epibionts were removed with a soft sponge without damaging the alga. Each F. vesiculosus piece was then marked using coloured threads. The 10 pieces of each $F$. vesiculosus specimen were evenly divided between 2 transparent plastic aquaria, each thus containing 5 genetically identical F. vesiculosus pieces. Subsequently, the $F$. vesiculosus pieces were kept for $4 \mathrm{~d}$ without treatment to allow for the reduction of putative in situ grazing effects, which are known to occur within $4 \mathrm{~d}$ (Rohde \& Wahl 2008), and acclimatisation of alga to laboratory conditions (Fig. 1). At the same time, Idotea baltica and Littorina littorea specimens for use in 


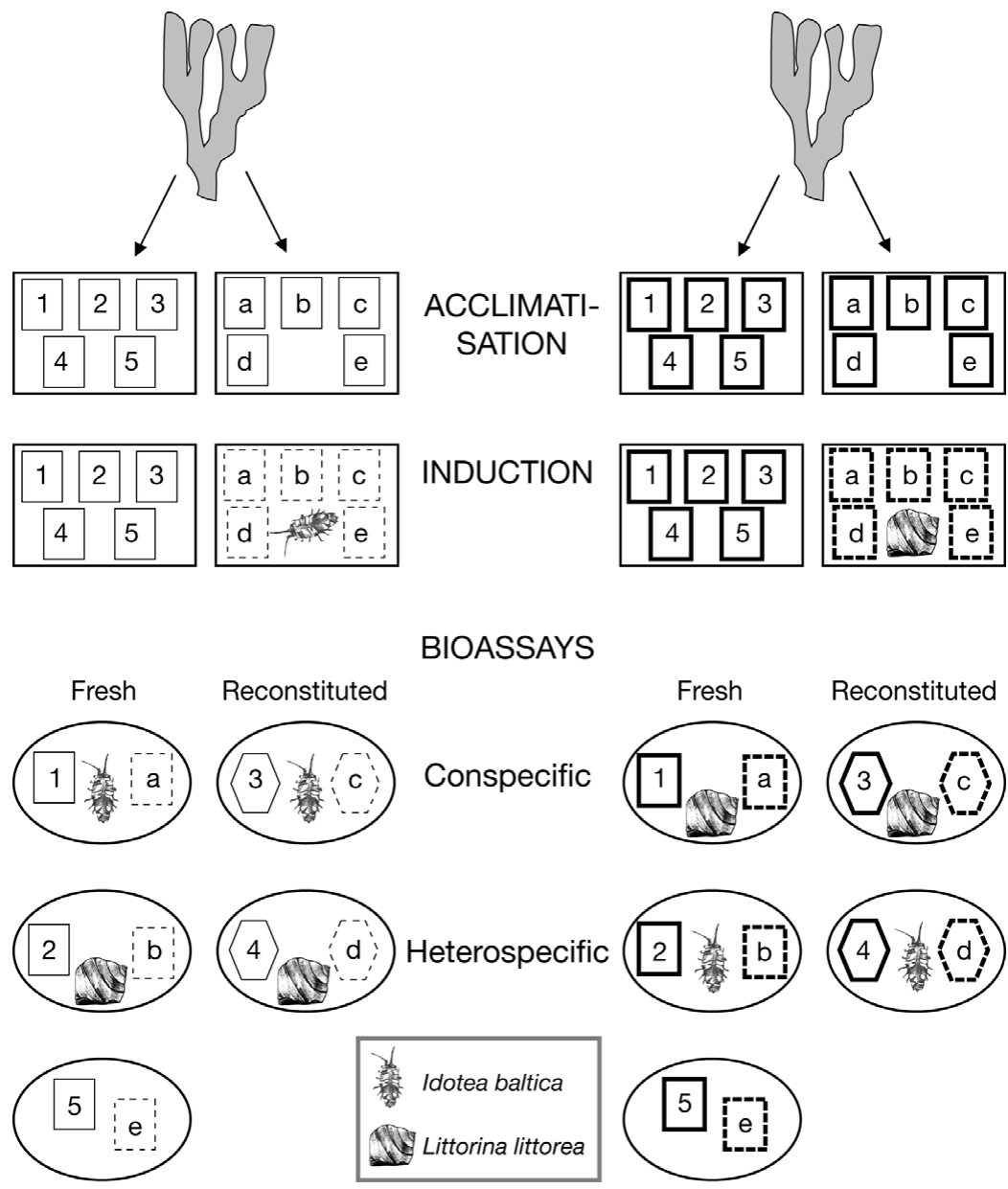

Fig. 1. Experimental design (only shown for a single replicate, requiring 2 algal specimens), testing for effects of trophic interactions between the brown seaweed Fucus vesiculosus and the 2 meso-herbivores Idotea baltica (isopod) and Littorina littorea (gastropod). Large rectangles indicate aquaria, each containing $5 \mathrm{~F}$. vesiculosus pieces (small rectangles). After a $4 \mathrm{~d}$ acclimatisation phase, grazers were added to half of the aquaria for $14 \mathrm{~d}$ (induction phase). Pieces of $F$. vesiculosus grazed by $I$. baltica and $L$. littorea (thin and thick dashed rectangles, respectively) were then transferred to feeding arenas (ovals) for 2-choice feeding assays. Numbers and letters label control and grazed pieces of $F$. vesiculosus, respectively, while rectangles and hexagons indicate fresh and reconstituted pieces of $F$. vesiculosus in feeding assays, respectively. For clarity, autogenic controls of reconstituted food were omitted
$0.3 \mathrm{l} \mathrm{h}^{-1}$. In both regions, fluorescent tubes illuminated each aquaria at a total irradiance of $65.5 \pm 2 \mu \mathrm{mol} \mathrm{m}{ }^{-2} \mathrm{~s}^{-1}$ (LI-COR, UWQ 6534) off Kiel (Baltic Sea) and of $34.4 \pm 2.5 \mu \mathrm{mol} \mathrm{m} \mathrm{m}^{-2} \mathrm{~s}^{-1}$ (LICOR, UWQ 6534) off Helgoland (North Sea) with a $12 \mathrm{~h}$ light:12 h dark cycle. These light regimes corresponded to ambient photosynthetically active radiation levels at $1 \mathrm{~m}$ water depth during the time when the experiments were conducted.

During $14 \mathrm{~d}$ of induction, algal pieces either were left without grazers ('control') or were exposed to grazing ('grazed'). Potential defences in the seaweed were induced by direct grazing consisting of adding either 15 Idotea baltica or 15 Littorina littorea (hereafter 'inducer') to each of 10 aquaria (Fig. 1). Aquaria were covered with a wire mesh (Kiel) or Perspex plates (Helgoland) to prevent $L$. littorea emigration from the aquaria. Throughout the induction phase, pieces of Fucus vesiculosus were visually checked for the occurrence of feeding damage to confirm that all algal pieces were consumed by grazers. In addition, measuring the consumption rates of $3 F$. vesiculosus pieces per aquarium $(n=10)$ during the induction phase (only North Sea) revealed no significant differences in grazing impact within aquaria (see 'Results'). At the end of the induction phase, all inducers were removed from the set-up and returned to the sea.

Bioassays: After the induction phase, herbivory-induced changes in algal palatability were tested by 2 types of choice feeding assays comparing the consumption of grazed and nongrazed algal pieces (Fig. 1).

the experiment were incubated in an aerated container (50 1) with water flow-through and fed on a mixed algal diet.

In both regions, the aquaria were supplied with local seawater. Off Kiel (Baltic Sea), seawater from the nearby Kiel Fjord was UV-sterilized (hw-Wiegand water sterilizer 500), filtered $(1.2 \mu \mathrm{m})$, and stored in a tank (150 l) before supplying the individual aquaria $(2.9 \mathrm{l})$ at a flow rate of $0.25 \mathrm{l} \mathrm{h}^{-1}$. Off Helgoland (North Sea), seawater from the North Sea was filtered by synthetic cotton and stored in a tank (200 l) from which each aquarium (8 l) was supplied at a flow rate of $1.2 \pm$
In the first type of assay, the palatability of previously grazed versus un-grazed fresh algal pieces was tested to detect induced responses of a chemical and/or morphological nature. After algal pieces were blotted with paper towels for $15 \mathrm{~s}$ and spun 10 times in a salad spinner, then they were weighed to the nearest $0.001 \mathrm{~g}$ on a balance (Sartorius LE323S). One previously grazed and 1 non-grazed piece of Fucus vesiculosus were transferred into a feeding arena (glass Petri dish, taining $1.5 \mathrm{l}$ of seawater. Each feeding arena contained either 6 Littorina littorea or 6 Idotea baltica, where $25 \mathrm{~cm}$ diameter, termed experimental unit [EU]) con- 
either the same or different specimens were used for induction and consumption (hereafter 'consumer') (Fig. 1 ; total 40 EUs, $\mathrm{n}=10$ ). To avoid confounding effects of grazer familiarity with previously grazed food, only naïve individuals without prior contact with the test algae were used as consumers. The EUs during the feeding assays were maintained under the same light regime as that used during the induction phase. Seawater was changed every $12 \mathrm{~h}$. Algal pieces were reweighed after $3 \mathrm{~d}$. To account for non-feedingrelated changes in wet mass (i.e. autogenic changes) during bioassays, feeding rates were corrected using the formula (equation from Cronin \& Hay 1996): $T_{\text {start }} \times$ $\left(C_{\text {end }} / C_{\text {start }}\right)-T_{\text {end, }}$ where $T_{\text {start }}$ and $T_{\text {end }}$ represent initial and final wet mass of an assayed $F$. vesiculosus piece, respectively, and $C_{\text {start }}$ and $C_{\text {end }}$ represent initial and final mass of the autogenic control piece, respectively. A significant preference of non-grazed over previously grazed $F$. vesiculosus pieces was interpreted as an induction of anti-herbivory defences. Autogenic changes in seaweed wet mass yielded in some cases negative consumption rates, i.e. growth in the presence of grazers more than compensated feeding loss.

The second type of feeding assay used reconstituted Fucus vesiculosus, in which any morphological defence was destroyed in the alga, but its chemistry preserved, to assess whether induced anti-herbivory defences were of chemical in nature. To reconstitute $F$. vesiculosus, algal pieces were freeze-dried after the induction phase, ground to a homogenous fine powder with a mortar and pestle, and $0.5 \mathrm{~g}$ of this powder was suspended in $2 \mathrm{ml}$ distilled water. The molten agar ( $0.09 \mathrm{~g}$ in $2.5 \mathrm{ml}$ distilled water) was mixed, after cooling to $55^{\circ} \mathrm{C}$, with the $F$. vesiculosus suspension, poured over a mosquito net $\left(1 \mathrm{~mm}^{2}\right.$ mesh size $)$ and flattened between 2 glass plates (methods adapted from Hay et al. 1994). After solidification, food pellets of $15 \times$ $15 \mathrm{~mm}^{2}$ were cut from $F$. vesiculosus-agar mixtures and marked by different incision patterns to distinguish pellets originating from control and grazed treatments. One control and 1 grazed pellet were transferred into a feeding arena (EU) with isopods or snails for $36 \mathrm{~h}$ (Fig. 1; total $40 \mathrm{EUs}, \mathrm{n}=10$ ) under conditions similar to those in the fresh bioassay. Feeding rates were determined by counting the number of empty mosquito net cells in the food pellets at the end of 2-choice feeding assays.

Statistical analysis. Since the 2 regions differ in a number of environmental factors, we did not attempt to interpret the absolute differences in consumption rates between 2 sites, but restricted our analysis to withinregion comparisons. In both Baltic and North Sea data, consumption rates of fresh and reconstituted alga were analyzed using 3-factorial repeated-measures ANOVAs. Consumption rates from 1 feeding assay were the repeated measure (fixed, 2 levels: grazed and control), while the identity of the inducer (fixed, 2 levels: Littorina littorea and Idotea baltica) and type of consumer (fixed, 2 levels: L. littorea and I. baltica) represented orthogonal grouping factors. Testing for sphericity was not relevant because the repeated measure had only 2 treatments (Quinn \& Keough 2002). Due to ambiguous selection of an appropriate error term for post hoc analysis involving within-subject by between-group interactions (Winer et al. 1991), 1 -tailed paired $t$-tests were performed as alternative post hoc tests with sequential Bonferroni adjustment to account for the number of comparisons made during analysis (i.e. $k=2$, where $k$ refers to the number of levels of the between-group factor; Rice 1989).

\section{RESULTS}

\section{Induction phase}

Idotea baltica and Littorina littorea consumed on average 14 and $15 \%$ of the Fucus vesiculosus pieces during the induction phase, respectively. Direct measurements of consumption (only North Sea) and visual inspections of algae for grazing marks (both study sites) confirmed that all $F$. vesiculosus pieces in each aquarium were equally consumed by both grazer species.

\section{Fresh food assays}

\section{Baltic Sea}

Consumption was significantly lower in grazertreated algal pieces than in the non-grazed pieces (Table 1, Fig. 2a). The absence of significant interactions suggests that this effect was independent of inducer identity and consumer identity (Table 1).

\section{North Sea}

Herbivores significantly preferred non-grazed pieces by $51 \%$ over previously grazed Fucus vesiculosus pieces (Table 1, Fig. 2b). In contrast to the lack of interaction with inducer identity, previous grazing had a significant interaction with consumer identity; this indicates that the efficacy of anti-herbivory defences depends on the consumer (Table 1). When Idotea baltica was the consumer, the non-grazed algae were significantly preferred, by $29 \%$, over the grazed $F$. vesiculosus pieces (paired $t$-test: $t_{19}=6.31$, $\mathrm{p}_{\text {corrected }}<$ 0.025), while Littorina littorea showed no significant preference (paired $t$-test: $t_{19}=0.26, \mathrm{p}_{\text {corrected }}>0.025$ ). 
Table 1. Results of 3-factorial repeated-measures ANOVA from the Baltic Sea and the North Sea, comparing feeding rates affected by previous grazing $\left(\mathrm{G}_{;} 2\right.$ levels, non-grazing and grazing), the identity of the inducer ( $\mathrm{I}_{i} 2$ levels, Idotea baltica and Littorina littorea), and the identity of the consumer $\left(C_{i} 2\right.$ levels, $I$. baltica and L. littorea). Consumption was assessed in 2-choice bioassays using either fresh or reconstituted pieces of Fucus vesiculosus $(\mathrm{n}=10)$

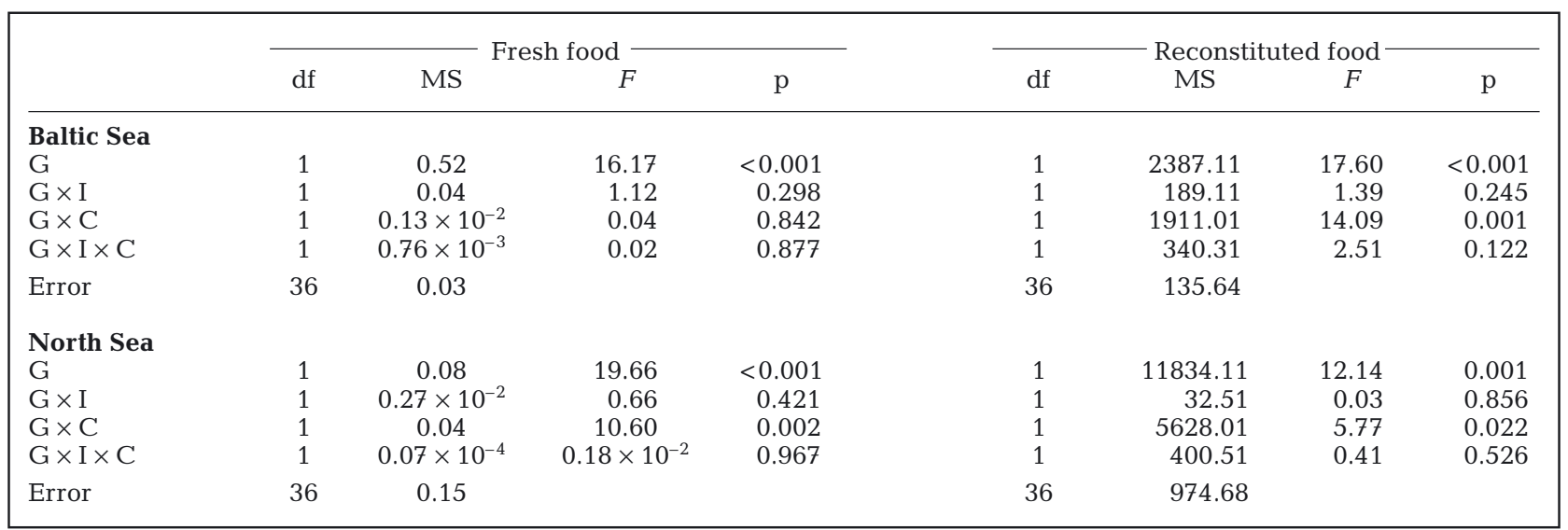
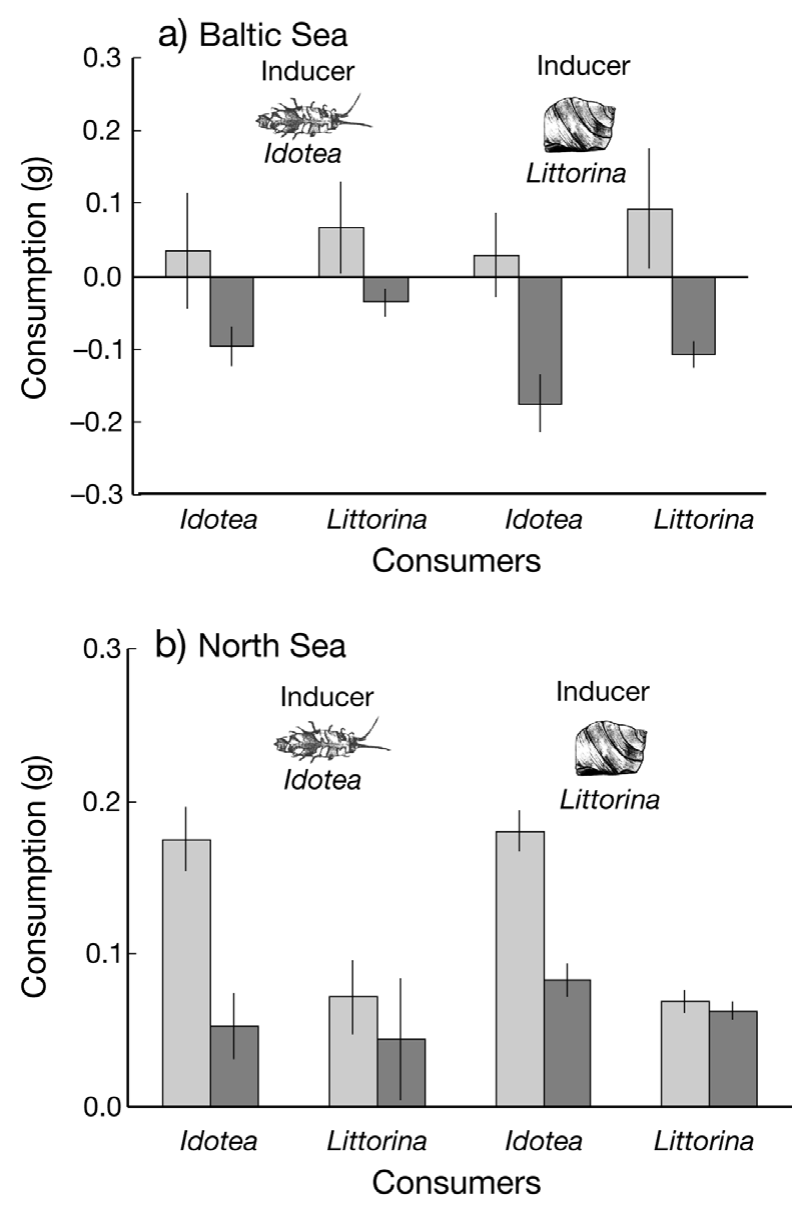

Fig. 2. Mean $( \pm \mathrm{SEM})$ consumption rates of control (light grey bars) and grazed (dark grey bars) pieces of fresh Fucus vesiculosus from the (a) Baltic and (b) North Seas $(\mathrm{n}=10)$. Pictures of grazers above the graphs indicate the species used during the induction phase (inducer), while the names below the graphs indicate the species of grazer used in the feeding assays (consumer)

\section{Reconstituted food assays}

Baltic Sea

Control pieces of non-induced Fucus vesiculosus were preferred 2.3 times over induced pieces (Table 1, Fig. 3a). The previous grazing-effect varied on consumer identity, regardless of inducer identity (Table 1). Idotea baltica as the consumer significantly preferred non-grazed pellets rather than previously grazed pellets (paired $t$-test: $t_{19}=3.91, \mathrm{p}_{\text {corrected }}<0.025$ ), whereas the consumer Littorina littorea did not show a significant preference between the 2 types of food (paired $t$ test: $t_{19}=0.26$, $\mathrm{p}_{\text {corrected }}>0.025$ ).

\section{North Sea}

Similar to assays using fresh Fucus vesiculosus pieces, overall consumption of control pellets was significantly higher than that of previously grazed F. vesiculosus pellets (Table 1, Fig. 3b). The effect of previous grazing was not significantly different between inducer species, but it was between consumers (Table 1). The consumer Idotea baltica significantly preferred ungrazed over grazed $F$. vesiculosus pellets; in contrast, Littorina littorea showed no preference (paired $t$-test: $I$. baltica $t_{19}=3.46, \mathrm{p}_{\text {corrected }}<0.025$; L. littorea $\left.t_{19}=1.11, \mathrm{p}_{\text {corrected }}>0.025\right)$.

\section{DISCUSSION}

Meso-grazers induced chemical defence in Fucus vesiculosus in both regions studied. How much feeding was reduced by these defences varied with con- 

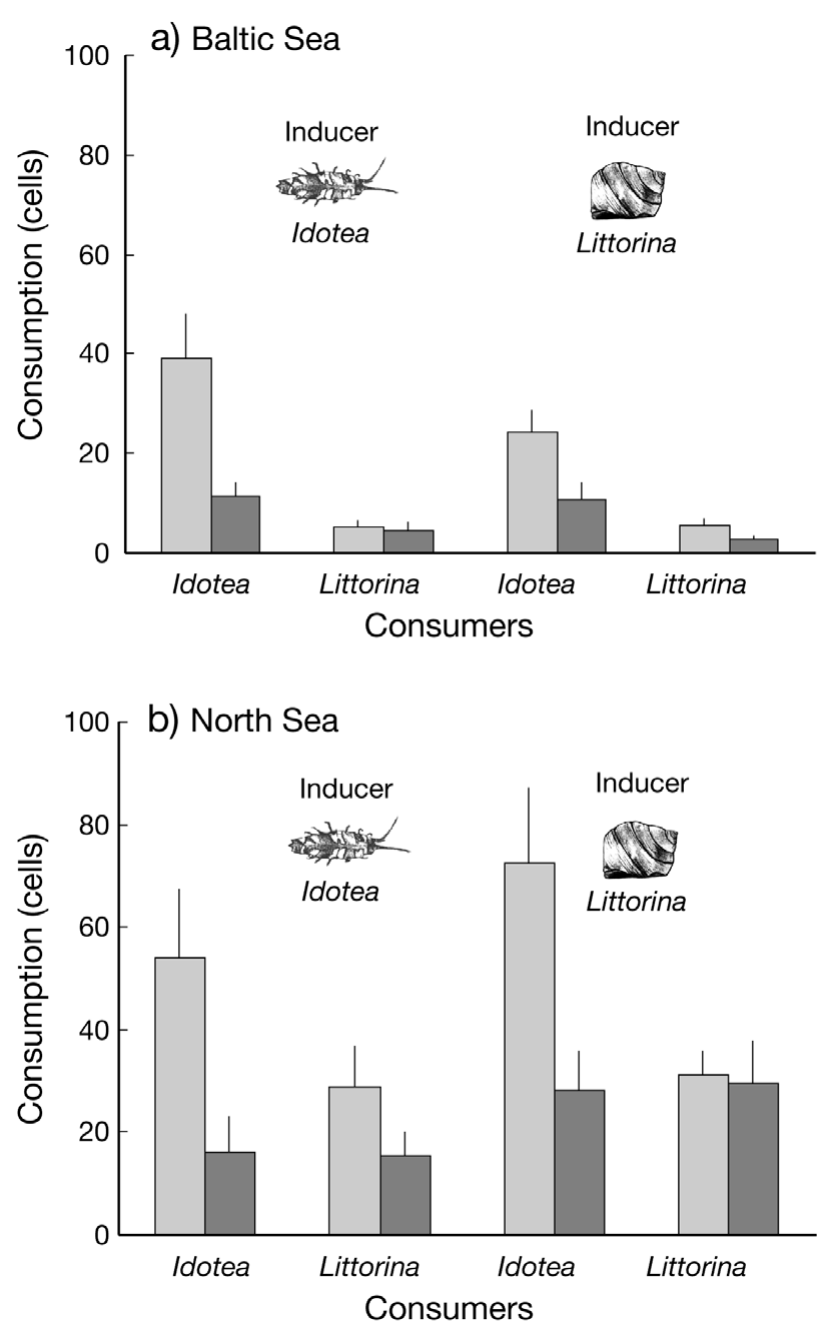

Fig. 3. Mean (+SEM) consumption rates of control and grazed pieces of reconstituted Fucus vesiculosus food from the (a) Baltic and (b) North Seas $(n=10)$. Symbols as in Fig. 2

sumer identity in 2 regions. Idotea baltica might be a more sensitive responder to grazing-induced modification in algal palatability than Littorina littorea.

The observed consistent preference of previously non-grazed over grazed pieces of Fucus vesiculosus using fresh or reconstituted food indicates that grazing can change some chemical seaweed trait(s). Chemical anti-herbivore defences have been described in F. vesiculosus (Rohde et al. 2004, Rohde \& Wahl 2008) and in other species of fucoids (Toth \& Pavia 2000, Taylor et al. 2002, Koivikko et al. 2005).

Quality and quantity of induced defences seems to be independent of inducer identity, at least for the 2 herbivore species tested, and the resulting patterns appeared to be surprisingly consistent. Regardless of whether the inducer was a con- or heterospecific species, Idotea baltica preferred non-grazed pellets over grazed ones in the North and Baltic Seas. Similarly, the preference pattern displayed by Littorina littorea did not depend on the inducer species. Tendencies similar to those shown in the reconstituted food assays were found in the other assays using live algal pieces. While the inducer species and region did not change the pattern, the sensitivity of the consumer species did. In all instances, L. littorea was more tolerant towards the chemical defences of Fucus vesiculosus than was $I$. baltica.

To our knowledge, only Long et al. (2007) have previously investigated the species-specific effects of induced seaweed responses using diverse herbivore species. In their study, grazing by the periwinkle Littorina obtusata reduced consumption rates of L. littorea, $L$. obtusata and Idotea baltica on Fucus vesiculosus, while previous grazing by L. littorea did not affect the palatability of $F$. vesiculosus for any of the 3 herbivores. While they suggested that inducer identity matters for the efficacy of the induced defence, we additionally show here that sensitivity to the induced defence may vary substantially among consumer species. Notably, I. baltica, but not L. littorea, were efficiently deterred by induced algae. Thus, all 3 components, the capacity of herbivores to trigger defence induction, the ability of the algal prey to react to grazing by inducing a defence, and the sensitivity of local herbivore species to this induced defence (i.e. herbivore offence; Sotka \& Whalen 2008) will determine the outcome of this multilateral interaction.

Differences in the responses of herbivores to inducible defences can cause plant-mediated interactions to appear asymmetric (Kaplan \& Denno 2007). An induction of anti-herbivory defences has been shown to increase the feeding dispersal, as well as the frequency of grazer movements (Borell et al. 2004). More mobile grazers like Idotea baltica may increase foraging activity in response to induced chemical seaweed defences and migrate to less well-defended prey, while slow moving grazers like Littorina littorea have to cope with the defences longer. In combination with the possibility to gain protection from defended prey, this may have selected for greater tolerance in slow moving meso-grazers (i.e. Sotka \& Whalen 2008), which has also been demonstrated in terrestrial systems (reviewed by Karban \& Agrawal 2002).

Studies on multiple herbivore interactions mediated by the traits of a host alga are just emerging for the marine community. The presence of multiple herbivore species that differ in their degrees of sensitivity towards defences will put some selective pressure on the defence traits of the host plant. This knowledge regarding consumer-prey interactions is highly desirable, because the intensity and directions in consumerconsumer interactions can be determined by the traitmediated effects of prey (Trussell et al. 2003, Creel \& 
Christianson 2008). Assessing the contribution of indirect trait-mediated effects in species interactions will help to refine existing knowledge on species interactions towards a more realistic perspective of the interactions occurring in the overall food web.

Acknowledgements. Assistance in the field by Andreas Wagner is acknowledged. We are grateful to Michael Grose and the anonymous reviewers for constructive comments to improve the manuscript.

\section{LITERATURE CITED}

Baldwin IT, Halitschke R, Paschold A, von Dahl CC, Preston CA (2006) Volatile signaling in plant-plant interactions: 'talking trees' in the genomics era. Science 311:812-815

Bergström L, Tatanenkovo A, Johannesson K, Johsson RB (2005) Genetic and morphological identification of Fucus radicans sp. nov. (Fucales, Phaeophyceae) in the brackish Baltic Sea. J Phycol 41:1025-1038

Borell EM, Foggo A, Coleman RA (2004) Induced resistance in intertidal macroalgae modifies feeding behaviour of herbivorous snails. Oecologia 140:328-334

Buschbaum C, Chapman AS, Saier B (2006) How an introduced seaweed can affect epibiota diversity in different coastal systems. Mar Biol 148:743-754

Coleman RA, Ramchunder SJ, Davies KM, Moody AJ, Foggo A (2007) Herbivore-induced infochemicals influence foraging behaviour in two intertidal predators. Oecologia 151:454-463

Creel S, Christianson D (2008) Relationships between direct predation and risk effects. Trends Ecol Evol 23:194-201

> Cronin G, Hay ME (1996) Susceptibility to herbivores depends on recent history of both the plant and animal. Ecology 77:1531-1543

Denno RF, Kaplan I (2007) Plant-mediated interactions in herbivorous insects: mechanisms, symmetry, and challenging the paradigms of competition past. In: Ohgushi T, Craig TP, Price JH (eds) Ecological communities: plant mediation in indirect interaction webs. Cambridge University Press, Cambridge, p 19-50

Duffy JE, Hay ME (2000) Strong impacts of grazing amphipods on the organization of a benthic community. Ecol Monogr 70:237-263

Fordyce JA (2006) The evolutionary consequences of ecological interactions mediated through phenotypic plasticity. J Exp Biol 209:2377-2383

Hay ME, Kappel QE, Fenical W (1994) Synergisms in plant defenses against herbivores: interactions of chemistry, calcification, and plant quality. Ecology 75:1714-1726

> Jormalainen V, Honkanen T, Vesakoski O (2008) Geographical divergence in host use ability of a marine herbivore in alga-grazer interaction. Evol Ecol 22:545-599

Kaplan I, Denno RF (2007) Interspecific interactions in phytophagous insects revisited: a quantitative assessment of competition theory. Ecol Lett 10:977-994

Karban R, Agrawal AA (2002) Herbivore offense. Annu Rev Ecol Syst 33:641-664

Karban R, Baldwin IT (1997) Induced responses to herbivory. University of Chicago Press, Chicago, IL

Editorial responsibility: Kenneth Heck Jr., Dauphin Island, Alabama, USA
Karban R, Nagasaka K (2004) Are defenses of wild radish populations well matched with variability and predictability of herbivory? Evol Ecol 18:283-301

Koivikko R, Loponen J, Honkanen T, Jormalainen V (2005) Contents of soluble, cell-wall-bound and exuded phlorotannins in the brown alga Fucus vesiculosus with implications on their ecological functions. J Chem Ecol 31:195-212

Long JD, Trussell GC (2007) Geographic variation in seaweed induced responses to herbivory. Mar Ecol Prog Ser 333: $75-80$

> Long JD, Hamilton RS, Mitchell JL (2007) Asymmetric competition via induced resistance: specialist herbivores indirectly suppress generalist preference and populations. Ecology 88:1232-1240

> Ohgushi T (2005) Indirect interaction webs: herbivoreinduced effects through trait change in plants. Annu Rev Ecol Evol Syst 36:81-105

Peacor SD, Werner EE (2001) The contribution of trait-mediated indirect effects to the net effects of a predator. Proc Natl Acad Sci USA 98:3904-3908

> Poore AGB, Hill NA, Sotka E (2007) Phylogenetic and geographic variation in host breadth and composition by herbivorous amphipods in the family Ampithoidae. Evolution 62:21-38

Quinn GP, Keough MJ (2002) Experimental design and data analysis for biologists. University Press, Cambridge

$>$ Rice WR (1989) Analyzing tables of statistical tests. Evolution 43:223-225

> Rohde S, Wahl M (2008) Temporal dynamics of induced resistance in a marine macroalga: time lag of induction and reduction in Fucus vesiculosus. J Exp Mar Biol Ecol 367: $227-229$

Rohde S, Molis M, Wahl M (2004) Regulation of anti-herbivore defence by Fucus vesiculosus in response to various cues. J Ecol 92:1011-1018

> Schmitz O, Krivan V, Ovadia O (2004) Trophic cascades: the primacy of trait-mediated indirect interactions. Ecol Lett 7: $153-163$

Sotka EE, Hay ME (2002) Geographic variation among herbivore populations in tolerance for a chemically rich seaweed. Ecology 83:2721-2735

Sotka EE, Whalen KE (2008) Herbivore offense in the sea: the detoxification and transport of algal secondary metabolites. In: Amsler C (ed) Algal chemical ecology. Blackwell, Oxford, p 203-228

Strong DR, Lawton JH, Southwood RI (1984) Insects on plants. Harvard University Press, Cambridge, MA

Taylor RB, Sotka E, Hay ME (2002) Tissue-specific induction of herbivore resistance: seaweed response to amphipod grazing. Oecologia 132:68-76

Toth GB, Pavia H (2000) Water-borne cues induce chemical defense in a marine alga (Ascophyllum nodosum). Proc Natl Acad Sci USA 97:14418-14420

Toth G, Pavia H (2007) Induced herbivore resistance in seaweeds: a meta-analysis. J Ecol 95:425-434

> Trussell GC, Ewanchuk PJ, Bertness MD (2003) Trait-mediated effects in rocky intertidal food chains: predator risk cues alter prey feeding rates. Ecology 84:629-640

> Van Zandt PA, Agrawal AA (2004) Community-wide impacts of herbivore-induced plant responses in milkweed (Asclepias syriaca). Ecology 85:2616-2629

Winer BJ, Brown DR, Michels KM (1991) Statistical principles in experimental design. McGraw-Hill, New York, NY

Submitted: January 26, 2009; Accepted: February 24, 2010

Proofs received from author(s): May 5, 2010 